\title{
Transatlantica
}

Revue d'études américaines. American Studies Journal

\section{The Modernist Poem or the Infinite Prolegomena}

\section{Aurore Clavier}

\section{(2) OpenEdition \\ Journals}

Electronic version

URL: https://journals.openedition.org/transatlantica/15232

DOI: 10.4000/transatlantica.15232

ISSN: $1765-2766$

Publisher

Association française d'Etudes Américaines (AFEA)

\section{Electronic reference}

Aurore Clavier, "The Modernist Poem or the Infinite Prolegomena", Transatlantica [Online], 1 | 2020,

Online since 15 December 2020, connection on 01 February 2023. URL: http://

journals.openedition.org/transatlantica/15232 ; DOI: https://doi.org/10.4000/transatlantica.15232

This text was automatically generated on 1 February 2023

\section{(c) (i) () $\Theta$}

Creative Commons - Attribution-NonCommercial-NoDerivatives 4.0 International - CC BY-NC-ND 4.0 https://creativecommons.org/licenses/by-nc-nd/4.0/ 


\title{
The Modernist Poem or the Infinite Prolegomena
}

\author{
Aurore Clavier
}

\section{"[T]o begin to begin again"1: Making Ends Meet?}

1 I would like to begin with the shape of a silence, with what is both a parenthesis and a conclusion, or what appears, at least, like a suspended thought. At the close of his essay "The End of the Poem," Giorgio Agamben ponders:

(Wittgenstein once wrote that "philosophy should really only be poeticized" [Philosophie dürfte man eigentlich nur dichten]. Insofar as it acts as if sound and sense coincided in its discourse, philosophical prose may risk falling into banality; it may risk, in other words, lacking thought. As for poetry, one could say, on the contrary, that it is threatened by an excess of tension and thought. Or, rather, paraphrasing Wittgenstein, that poetry should really only be philosophized.) (Agamben, 1999 115; author's punctuation)

Expanding upon Wittgenstein's words-rather, probably, than paraphrasing themAgamben's final statement concludes less than it launches thought anew, and thus provides a restive coda to an essay entirely focused on the question of the end. As its title makes clear, the text revolves around what Agamben considers a true generic crisis, around that final line where sound and sense are doomed to coincide, making enjambment impossible and jeopardizing the very definition of verse, for, he writes, "if poetry is defined precisely by the possibility of enjambment, it follows that the last verse of a poem is not a verse" (Agamben, 1999 112).

2 Yet following Agamben's last logical twist, we discover that this "crise de vers," as he names it after Stéphane Mallarmé's essay (Mallarmé 1897; quoted in Agamben, 1999 113) does not necessarily entail the dissolution of the poem into common speech. Rather it opens it up to a more fertile form of coincidence. As it reaches to a close, the poem does not so much end as it takes another turn, or stretches beyond its own margin, out to a new form of space. In other words, the final line does not only dramatize the fusion of the semiotic and the semantic, but also enables the reunion of 
poetry and philosophy, two domains long kept apart by Western tradition, as the philosopher deplored in the prologue to his 1977 Stanzas:

The scission in question is that between poetry and philosophy, between the poetic word and the word of thought. This split is so fundamental to our cultural tradition that Plato could already declare it "an ancient enmity." According to a conception that is only implicitly contained in the Platonic critique of poetry, but that has in modern times acquired a hegemonic character, the scission of the word is construed to mean that poetry possesses its object without knowing it while philosophy knows its object without possessing it. In the West, the word is thus divided between a word that is unaware, as if fallen from the sky, and enjoys the object of knowledge by representing it in beautiful form and a word that has all seriousness and consciousness for itself but does not enjoy its object because it does not know how to represent it. (Agamben, 1997 vi-vii)

Resisting the scission described in that earlier essay, "the end of the poem" (Agamben 1999) therefore makes room for a middle, or rather, a meeting ground between philosophical and poetical writing, attaching verse, however fugitively, to the patient furrows of philosophical thought.

Enticing though this horizon looks, I propose to turn our gaze to the opposite end of the poem-if I may call it so-that is, to its beginning, and even more largely, to the poem as a beginning. Here again lie some of the most enduring features commonly evoked in definitions of the poetic genre. Though perhaps less conspicuous than the necessity of enjambment, the formal recurrence of the left margin, ${ }^{2}$ or the myth of compositional urgency-from ancient or romantic myths of inspiration ${ }^{3}$ to the Mallarmean coup de dés (Mallarmé 1914)-often tends to displace the poem's center of gravity to its very first vocal and creative movement, the initial breath or impulsion being viewed as the first locus of poetic essence. Elaborating on the reflection François Jullien propounds in his comparative study of Chinese and Western thought, The Book of Beginnings, we could be tempted to assert that the "first sentence" does not only "establi[sh], exud[e], an order that can no longer be undone; [in such a way that] one can only think within its orbit or in its wake" (Jullien, 2015 21), but also determines, in the case of a poem, the whole generic fate of the text. If the "first sentence," however discreetly, necessarily "folds the thinkable" (Jullien, 2015 21) along its own curve and holds it within the threads of its net, the first line or lines of a poem seem to engage something more, enmeshing us into the grid of critical categories at large. But what would become of this definitional bend, should this beginning never end, or even, should the poem itself never quite begin? What if the first line did not inaugurate the rise of poetic speech but chose to perpetuate itself well into the heart of the text? Refusing to "declare itself" (Stevens, 1997 15), but speaking, as it were, ahead of itself, would verse then cease to be verse? Could we not perceive in this liminal, or rather preliminary status, something like a temptation for the poem to escape its own repository, the stanza, and to reach out, from the edge, to the antechamber of philosophical thought?

\section{Modernism or the Stutters of Literary History}

One particular moment of poetic history accurately crystallizes this generic irresolution. This period, or movement, was famously obsessed with beginnings, to the point of receiving that convenient but sometimes reductive label, "Modernism," and 
seeing the ideal of novelty systematized into a perennial "tradition of the new" (Rosenberg 1982): ${ }^{4}$

The famous 'modern break with tradition' has lasted long enough to have produced its own tradition. Exactly one hundred years have passed since Baudelaire invited fugitives from the too-small world of memory to come aboard for his voyage in search of the new.

Since then there have come into being an art whose history, regardless of the credos of its practitioners, has consisted of leaps from vanguard to vanguard, and political mass movements whose aim has been the total renovation not only of social institutions but of man himself.

The new cannot become a tradition without giving rise to unique contradictions, myths, absurdities-often, creative absurdities.

Under the slogan, for a new art, a new reality, the most ancient superstitions have been exhumed, the most primitive rites re-enacted [...]. (Rosenberg, 1982 11-12) ${ }^{5}$

5 Yet for all its insistence on artistic inception, the period is rarely associated to any idea of indecision, literary history having preferred, it seems, to retain more assertive gestures, more unfaltering manners of commencing-the irruption of a "language of rupture" (Perloff 1986), ${ }^{6}$ the imperious injunction to "make it new" (a sentence whose philosophical origins have, quite significantly, often been misread or neglected), ${ }^{7}$ the publicized erection of foundational literary monuments such as The Waste Land, or the inauguration, by later critical discourse, of new eras, be it Pound's or Stevens's. This latter debate, the terms of which were famously retraced by Marjorie Perloff at the beginning of the 1980s, incidentally reveals the enduring schism at work, through the periodization of modernist poetry, between form and thought, or in Agamben's words, between poetic enjoyment and philosophical knowledge. Indeed, Perloff explains that the various scholars she mentions have tended to equate Modernism either with a Stevensian and post-Romantic inner meditation or with the Poundian preference for the fragmented surface of the work of art, opposing, in Perloff's own summarizing terms, thought and technique, the what and the how of poetic writing:

As Stevens himself sums up the difference, "The bare image and the image as symbol are the contrast" (Opus Posthumous 161). For Stevens, as for Stevensian critics, "Poetry as an imaginative thing consists of more than lies on the surface" (Opus Posthumous, 161). Poundians, on the other hand, are reluctant to generalize about poetry; rather, they want to show how modern poetry gives renewed attention precisely to what "lies on the surface." (Perloff, 1982 494)

6 Taking a closer look however, it soon appears that, underneath the literary eras initiated by such critical constructions, beyond the repeated outbreaks favored by historians of the avant-gardes, the course of Modernism was often punctuated by more hesitant beginnings, thus invalidating the forms of theoretical distinction Perloff describes and inviting us to consider, in one single embrace, the rise of thought and the lyric alike. One need only open the poetry book at the very first page(s) and consider in a new light what is often skipped or, at best skimmed (over?) too fast as a mere store for aesthetic quips and quick justifications, to discover a more shifting ground, where the poetic voice may grope and amble, even before determining its course. Quite tellingly, the word for this liminal site shares the same root as the one I have chosen for my title, prologues and prolegomena opening, as I hope to show, similar thresholds for speech.

7 Despite its significance for literary and scholarly circles, Williams's prologue to his early collection Kora in Hell: Improvisations (1920) could easily inspire this type of 
selective memory, viewed as it might be-when considered at all-as a mere collection of anecdotes, letters, conversations, praise and attacks involving various modernist personalities. Williams himself has often tended to blur the formal significance of his text in favor of a more biographical and contextual reading, as suggested by the prologue to the City Lights edition of the book (1957):

I felt I had to give some indication of myself to the people I knew; sound off; tell the world-especially my intimate friends-how I felt about them. All my gripes to other poets, all my loyalties to other poets, are here in the Prologue. It has been referred to many times because it includes extracts of important letters from people who influenced me in my career. (Williams, 1958 30)

Paradoxically, the prologue's position has long remained uncertain: as Webster Schott specifies in his own introduction to Kora in Hell, it was temporarily removed from subsequent editions of the collection after 1920, only to reappear in the posthumous volume Imaginations (1971) (Williams, 1971 3). However, in a comment appended to Williams's interview in I Wanted to Write a Poem, Edith Heal reasserts the significance of the prologue for its author, and for readers and critics at large:

We turned to the Prologue and I read a page or two aloud. Dr. Williams said shyly: "Perhaps this is the first thing to show me to be a prose writer. As far as can be told, it is the first piece of continuous prose I remember writing." The Prologue, which Dr. Williams feels is significant because it has been quoted and referred to so often, has been reprinted in Selected Essays, Random House, 1954. (Williams, 1958 31)

9 A more consistent reading quickly confirms the importance of this preliminary text and reveals the tight weaving that links it to the main body of the work. Not only does the former text provide access to the context of composition and to the questions addressed by writers and artists at the time, but it is also, quite literally, cut from the same cloth as the collection itself, partaking of a common creative impulse and, whatever the interpretive function of the comments might suggest, displaying the same disjunctive logic as the selection of fragments Dr. Williams jotted down after each day's work:

I thought at first to adjoin to each improvisation a more or less opaque commentary. But the mechanical interference that would result makes this inadvisable. Instead I have placed some of them in the preface, where without losing their original intention (see reference numerals at the beginning of each) they relieve the later text and also add their weight to my present fragmentary argument. (Williams, 1971 16)

10 That "the Prologue [...] is really an Epilogue" (Williams, 1958 30) containing comments written in the aftermath of the improvisations does not preclude its inchoative value, quite to the contrary.

The book was composed backward. The Improvisations which I have told you about came first; then the Interpretations which appear below the dividing line. Next I arrived at a title and found the Stuart Davis drawing.

I am indebted to Pound for the title. We had talked about Kora, the Greek parallel of Persephone, the legend of Springtime captured and taken to Hades. I thought of myself as Springtime and I felt I was on my way to Hell (but I didn't go very far). This was what the Improvisations were trying to say. I did not bother to include Interpretations for all Improvisations. I used to get very excited; the Interpretations had as much importance to me as the statements. Finally, when it was all done, I thought of the Prologue which is really an Epilogue. It was always my own mind I was making up." (Williams, 1958 29-30) 
While the repeated improvisations, fulgurant and open-ended as they appear, along with their tentative comments, remain essentially imperfective, the genesis of the prologue excludes any form of closure, its placement pointing instead to Williams's efforts to "mak[e] up [his] mind" (Williams, 1958 29-30) and give shape to a text which, though fully written and published, remained yet to be formulated. To a certain extent, we could say that a large number of Williams's works, up to the book of interviews whose title, I Wanted to Write a Poem, suggests the ongoing prehistory of his published books, are marked by a similar transfusion of the compositional effort towards its textual threshold, the magma chamber of the preface actively modelling the poem, preventing any cooling off of the first burst of creative material.

11 For instance, if no apparent preface informs the reading of Spring and All (1923), this experimental piece written a few years after Kora in Hell, under the spell of American Dadaism, rushes the reader through a seemingly random association of prose and verse. Against the onward pull of the sequence however, the erratic numbering of chapters, or the seemingly unfinished sentences and non-sequiturs that "link" the various parts of the book, tend to blur all spatial, temporal and bibliographic coordinates, thus maintaining the reader on the threshold of a potential poem, heralded by the stuttering announcements of a critical spring:

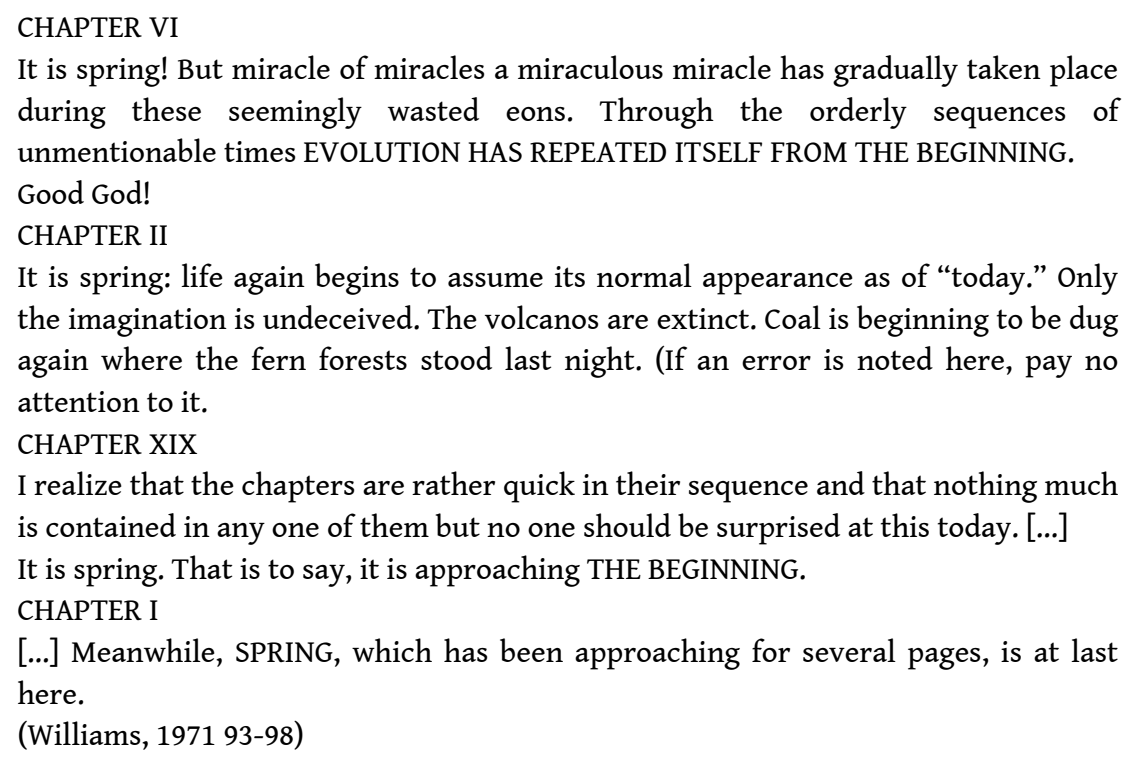

12 Though perhaps more visibly structured in form, Williams's later opus Paterson perpetuates this obsession for inception and similarly questions the frontier between the poem and its paratext: its flow of heterogeneous elements is delayed by a twofold entrance, a broken epigraph, and a preface in verse whose very placement right below the title of Book One further contributes to integrating the paratext into the main text. 


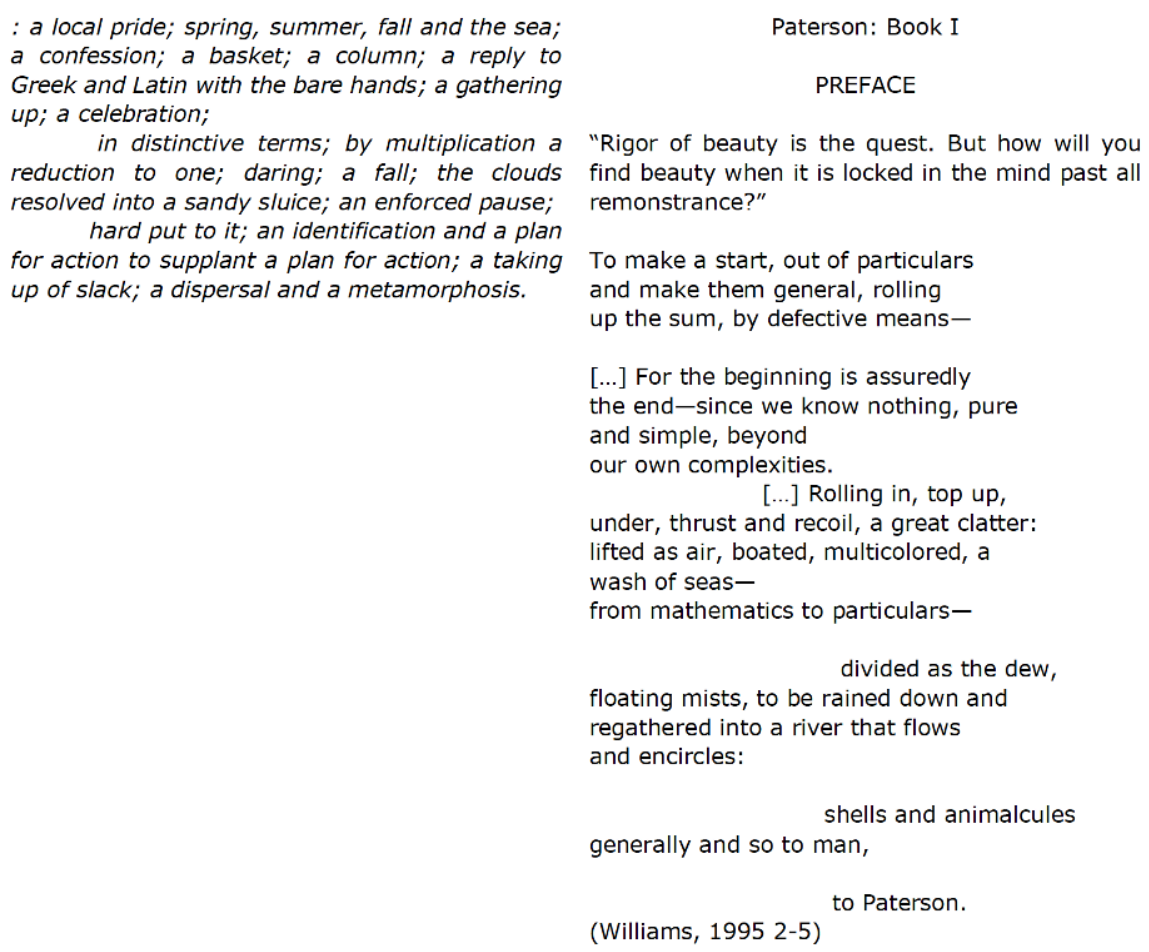

13 However central the image of the Passaic flowing to and through Paterson might appear in these opening pages, the reader is immediately prevented from relying on any linear progression. As the dislocated epigraph adumbrates, the course of the long poem and its metaphorical counterpart, the river, are marked by constant false starts, hesitations, ruptures, resurgences, if not sheer returns. Nature may still find its way in the suburban environment of the post-industrial city, but its various rhythmical patterns seem more erratic than cyclical. If the poem's images of winter, divorce, destruction and decay are indeed counterbalanced by more fertile equivalents, the five books making up Paterson do not so much embrace the recurring dynamics of death and rebirth as maintain writing in a liminal state of hesitancy where the gropings of poetic form espouse the self-reflexive meditations of the poet at work. Despite its prominence in Williams's later career, the long poem similarly excludes any sense of progression toward an ideal literary form at the scale of his whole oeuvre. Although Williams claimed to have found the sought-for rhythm of the variable foot while composing Book II, the structure of the long poem eventually invalidates any teleological construction, made as it is of ever-changing alternations of prose and verse, and more or less irregular meters, suggesting continued formal research.

One might be tempted to interpret such kinds of irresolution as a mere expression of the aesthetics of disjunction so consistently defended by Williams, whether in his critical or creative writings. And yet, a comparable hesitancy of beginnings repeatedly surfaces in the works of Wallace Stevens, an author whose relationship to the new may seem diametrically opposed to his friend Williams's. As Juliette Utard finely demonstrates in her study Wallace Stevens: Une Poétique du Fini (2018), Stevens's very own modernist explorations were less driven by an ongoing need for revision than by the perspective of finishing. That poetic closure remained a permanent horizon for the Stevensian opus (should it, in the end, turn out to be a mere vanishing point), is for 
instance evidenced in an early criticism he addressed to Williams, who in turn quoted it in his prologue to Kora in Hell:

My dear Williams,

........

What strikes me most about the poems themselves is their casual character. . . Personally I have a distaste for miscellany. [...] My idea is that in order to carry a thing to the extreme necessity to convey it one has to stick to it; ... Given a fixed point of view, realistic, imagistic or what you will, everything adjusts itself to that point of view; and the process of adjustment is a world in flux, as it should be for a poet. But to fidget with points of view leads always to new beginnings and incessant new beginnings lead to sterility. (Stevens, quoted in Williams, 1971 15)

If a poem or collection should necessarily begin, it should also be with a view, if not to ending, then at least, to finding a course, be it a changing one. Many of Stevens's texts therefore start by presenting themselves as constructed reasonings or, more accurately maybe, as thinking processes, evolving from the establishment of initial premises to their speculative or sensory examination. While some open with a rather simple statement: "The soul, he said, is composed / Of the external world," (Stevens, 1997 41), "Poetry is the supreme fiction, madame" (Stevens, 1997 47), "I am what is around me" (Stevens, 1997 70), others more explicitly borrow their formulations from the grammars of scientists, rhetoricians, or metaphysicians. Addressing a note to the reader's attention "The Comedian as the Letter C"'s initial premise, "Nota: man is the intelligence of his soil," is turned, in the middle of the poem, into an alternative foundation "Nota: his soil is man's intelligence. / That's better. That's worth crossing seas to find." (Stevens, 1997 22, 29). "The Glass of Water" similarly establishes an apparently firm starting point as it enunciates physical laws:

That the glass would melt in heat,

That the water would freeze in cold,

Shows that this object is merely a state,

One of many, between two poles. So,

In the metaphysical, there are these poles.

[...] And there in another state-the refractions,

The metaphysica, the plastic parts of poems

Crash in the mind.

(Stevens, 1997 21-22)

"Connoisseur of Chaos" carefully presents the reader with logical postulates it then proceeds to confront:

A. A violent order is disorder; and

B. A great disorder is an order. These

Two things are one. (Pages of illustrations.)

[...] A. Well, an old order is a violent one.

This proves nothing. Just one more truth, one more

Element in the immense disorder of truths.

B. It is April as I write. The wind

[...] But suppose the disorder of truths should ever come

To an order, most Plantagenet, most fixed ...

A great disorder is an order. Now, A

And B are not like statuary, posed

(Stevens, 1997 194)

17 A comparable process is found in "So-and-So Reclining on her Couch" which quickly converts the nude portrait it sketches out into various "projections," at once cast as geometrical constructs and philosophical abstractions. 
On her side, reclining on her elbow.

This mechanism, this apparition,

Suppose we call it Projection A.

[...] If just above her head there hung,

Suspended in air, the slightest crown

of Gothic prong and practick bright,

The suspension, as in solid space,

The suspending hand withdrawn, would be

An invisible gesture. Let this be called

Projection B. To get at the thing

Without gestures is to get at it as

Idea. She floats in the contention, the flux

Between the thing as idea and

The idea as thing. She is half who made her.

This is the final Projection, $C$.

(Stevens, 1997 262-263)

But despite their apparent determination, and under the constant need to readjust themselves to the fluctuations of the surrounding world ("It is posed and it is posed / What in nature merely grows," Stevens, 1997 182), these demonstrations hardly ever seem to reach any final conclusion, repeatedly requiring instead a necessary "restatement" (Stevens, 1997 118) of the prolegomena. If then, to quote Stevens' recommendation to Williams, it is preferable not to "fidget with points of view," the instability of the poetic set course invites an ironical rapprochement between Williams's reluctance to completion and the Stevensian necessity to start over. Oscillating between a bare and florid version of the world, the Comedian's mock Odyssey, for instance, is faced with many false starts, before ending with a complete revolution, that is, right where it started:

The world, a turnip once so readily plucked,

Sacked up and carried overseas, daubed out

of its ancient purple, pruned to the fertile main,

And sown again by the stiffest realist,

Came reproduced in purple, family font,

The same insoluble lump. (Stevens, 1997 36)

In the same early collection, Harmonium, the logical speculation of "Metaphors of a Magnifico" gives way to a stuttering song "that will not declare itself" and literally unravels as the "meaning escapes" and as the mind is left to wander:

Twenty men crossing a bridge,

Into a village,

Are twenty men crossing twenty bridges,

Into twenty villages,

Or one man

Crossing a single bridge into a village.

This is old song

That will not declare itself ...

Twenty men crossing a bridge,

Into a village,

Are

Twenty men crossing a bridge

Into a village.

That will not declare itself

Yet is certain as meaning...

The boots of the men clump

On the boards of the bridge. 


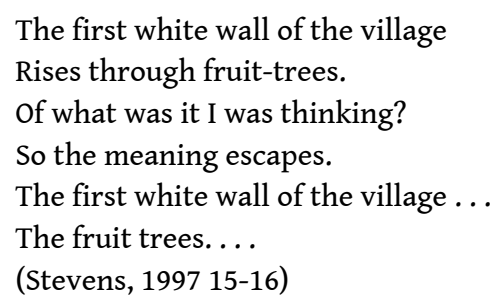

More than a failure of speech and a fall into silence, the final ellipses suggest the irresistible drift away from the poem's initially conclusive stance, as the men's invasive entrance, sustained by the implacable repetitions and marching cadence of the first lines, is diverted by various unfinished lines, scraps of observations whose ragged contours open the last stanza to new forms, where the poetic line may potentially meet the philosopher's budding contemplation.

21 Whether they follow the disjunctive mode of Williams's prologues, or the renewed adjustments of the Stevensian meditation, these sample texts do not only share a common bend toward a preliminary state of the poetic word, a state which, I should add, would correspond neither to the provisory incompleteness of the draft, nor to the tentacular accretion of the work in progress. Built as they are upon unstable premises, false starts and loose ends that invite new beginnings, these inchoative poems also display their common defiance of a certain Platonic tradition, the distrust of the scission described by Agamben and a belief in the possibility for poetry and philosophy to speak the same language, or more exactly perhaps, to speak from the same place. Refusing to endorse the hierarchy that would submit poetic illusion to philosophical truth, or even to merely defend the conception of two equivalent but separate ways of apprehending the world, the modernist poem becomes the very site where to confront reality and imagination, "things as they are" (Stevens, 1997 135) and "supreme fictions," (Stevens, 1997 47, 329), the particulars and the universals of human perception. ${ }^{8}$ Similarly, and although the two poets' interest in phenomenology or pragmatism has been thoroughly analyzed, the common ground sketched out here does not merely imply the transposition of the philosopher's words and concerns into the poem but rather delineates, however provisionally, the formal contours of a common attempt to investigate the world through language, whether poetic or philosophical.

\section{"The Placeless Place" 9 as a Common Ground}

In this light, one might be tempted to consider the text as accomplishing the longdesired contact between the object and its representation, achieving the dream of a reunited word that could, in Agamben's terms, "know" its object and "possess" it at the same time and thus fusing philosophical and poetical ideals. As is well known, most Anglo-American modernists proved particularly sensitive to this ideal, striving to transmute the poem into a physical reality, to give it the wholeness and consistence of "solid objects" (Virginia Woolf, 1920; quoted in Mao, 1998). If, as Douglas Mao summarizes, "[i]maginative writing in English has always included representations of solid objects, of course, from ekphrastic and allegorical devices anchoring the morals of entire works to ephemeral details generating what Roland Barthes called l'effet du réel [sic], [...] the high modernists introduced into their writings a self-conscious contemplation of the object qua object hitherto only sporadically anticipated" (Mao, 1998 xxvii). Paralleling a rich philosophical line Mao traces from Adorno's critique of 
Hegel to Baudrillard's attack on "the system of objects" (1968), the shift from the object's "marginal" or "metaphorical" function as a mere signifier to its central position in modernist poetics ${ }^{10}$ has been underlined by a wide variety of poetic practices such as collage, extensive catalogues, verbal hardness and precision, or by more theoretical statements efficiently contained-or isolated by criticism-within lapidary statements: "no ideas but in things" (Williams, 1995 6), "direct treatment of the 'thing,' whether subjective or objective" (Pound, 1954 3), "A poem should not mean / But be" (MacLeish, 1985 106-107), "the only way of expressing emotion in the form of art is by finding an 'objective correlative"' (Eliot, 1920 92); or the more ambiguous "imaginary gardens with real toads in them" (Moore, 2002 205).

As it lingers in the space of a poetic foreword, however, the object strangely seems to escape our grasp, as if, all the while investigating its philosophical value, the poem failed or refused to ever tie a definitive knot around it. If Wallace Stevens's oscillatory poetics notoriously epitomizes this tension, "divided" as it is, "perhaps even torn, between these two temptations, between imagination reducing reality to itself and reality reducing the imagination's power to impotence, [...] between high summer and deep winter, between ideas about the thing and the thing itself" (Critchley, 2005 85-86), whether at the scale of single poems or of his whole production, one could just as easily identify a similar reluctance to apprehend one's object in Williams, a poet more readily remembered, as we have seen, for his desired contact with "things" or "particulars." One of his most famous observations is a case in point:

so much depends
upon
a red wheel
barrow
glazed with rain
water
beside the white
chickens
(Williams, 1971 138)

24 Entranced as readers often are by the extreme concentration of this modernist epiphany-an effect emphasized by the poem's frequent inclusion into anthologies, and isolation from the original Spring and All sequence-they sometimes tend to forget that the poem does little more, after all, than enunciate the premise to a crucial, yet indefinite, consequence. However precise its description appears, however neat its visual and poetical lines, the red wheelbarrow is, ultimately, more of a foreword than an actual object, a virtual entity whose contours merely gesture towards a conditional space. If the onset of the poem presents itself as a meeting ground between speculative and poetical writing, then this site might be most accurately described as "the topology of the unreal" or the "topos outopos," the "placeless place" Agamben sketches out in his introduction to Stanzas:

From this vantage one can speak of a topology of the unreal. Perhaps the topos, for Aristotle "so difficult to grasp" but whose power is "marvelous and prior to all others" and which Plato, in the Sophist, conceives as a "third genre" of being, is not necessarily something "real." [...] We must still accustom ourselves to think of the "place" not as something spatial, but as something more original than space. Perhaps, following Plato's suggestion, we should think of it as a pure difference, yet one given the power to act such that "what is not, will in a certain sense be and what is, will in a certain sense not be. Only a philosophical topology, analogous to what in mathematics situs (analysis of site) in opposition to analysis magnitudinis 
(analysis of magnitude) would be adequate to the topos outopos, the placeless place whose Borromean knot we have tried to draw in these pages. Thus topological exploration is constantly oriented in the light of utopia. The claim that thematically sustains this inquiry into the void, to which it is constrained by its critical project, is precisely that only if one is capable of entering into relation with unreality and with the unappropriable as such is it possible to appropriate the real and the positive. (Agamben, 1997 xviii-xix). memorable instances of ars poetica, opening the field of literary prescription to philosophical doubt, turning the positive space of the poem into its photographic negative. Though McLeish's “Ars Poetica” (MacLeish, 1985 106-107) or Wallace Stevens's "Notes Towards a Supreme Fiction" (Stevens, 1997 329) propose telling ways of gesturing towards a potential poem, I wish to turn to an even more radical mode of deferral, which will serve as my conclusion (this article being no modernist poem, it has to end at some point): "Poetry" by Marianne Moore, a poet as notorious for her intellectual investigations into the concrete as for the formal radicalism of her line breaks and revisionary practice. Certainly, the title of this most emblematic piece seems to share none of the uncertainties of Stevens's "Prelude to Objects" (Stevens, 1997 179) and other "Prologues to What Is Possible" (Stevens, 1997 437). But whoever expects a well-established system of definitions and prescriptions will only find a barred entrance. The negative horizon is reinforced by the editorial history of the poem, which famously underwent several dozens of transformations over some fifty years of publication, up to an ultimate slashing down of the text to its first three lines, forcing the original beginning and end to collide ${ }^{11}$ :

I, too, dislike it.

Reading it, however, with a perfect contempt for it, one discovers in

it, after, a place for the genuine. (Moore, 1981 36)

Yet what could appear like a final rejection soon reveals itself as the only condition of access into the poem. Only by regarding poetry "with a perfect contempt for it" can we find "a place for the genuine." Only from the negation of poetry can "a topology of the unreal" surface, a hybrid and conditional space already sketched out in earlier versions of the poem, before disappearing into the marginal space of an endnote in the final version:

when dragged into prominence by half poets, the result is not poetry,

nor till the autocrats among us can be

"literalists of

Transatlantica, 1 | 2020 
the imagination"-above

insolence and triviality and can present

for inspection, imaginary gardens with real toads in them shall we have

it. In the meantime, if you demand on one hand, in defiance of their opinion-

the raw material of poetry in

all its rawness and

that which is on the other hand,

genuine, then you are interested in poetry.

(Moore, 2002 72-73, 206-207)

In the meantime however, poetry will have undergone a discreet, though most significant shift, initially contracting itself in an apparent silence, only to launch itself in a new shape, away from the generic category to which it was seemingly assigned. Through its conversational flow and the occasional stretches of the line far beyond the audible or visible limits of verse, "Poetry" does not only venture into the less defined realm of prose, this once threatening "other" Moore was always drawn to-like fellowmodernists Williams, or to a less provocative extent Stevens-, but it also sets foot on the more tentative path of the essay, this most capacious "genre" so tightly attached to the philosophical investigation. Negations, corrections and unstable premises thus form the shifting landmarks of a common space, where the poem is invited to share the pace of speculation, to follow the fresh impetus of the hunt Jean-Christophe Bailly defines as the true mode of the essay:

The essay withdraws and distances itself from [the] monumentality and [the] solidity [of the Euvre]. The thesis probably remains the constant temptation of the theoretical endeavor, but if the essay dedicates itself to it, it does so only in passing, through formulations that occur to it, but are spurred by its pace, by its impetus. I think this notion of speed is very important: saying that the essay is quick does not mean that it rushes through the problems it confronts, but describes its operating mode, reasserts its ties to the hatchings, the engagements of thought. At bottom, the essay mainly seeks to maintain some form of notation in its momentum, something that would partake of a sort of tactile thought. The notion of engagement is fundamental: it points to the beginning, to the point of departure, to irruption and it indicates resumption, connection; not what happens when two pieces of the same puzzle come together, but what occurs when one jumps from one spot to another, as when one follows what in French is called a pas japonais, and in English, I think, a stepping stone. Consequently, this progress would neither follow a pure logical chain, nor an erratic movement, and certainly not a sort of via media that would borrow from both, but a free deployment and a careful crossing led by a kind of avidity, as if one were on the lookout, after a glimpsed at but elusive truth-just like an animal running off through the woods. (Bailly, 2015 118-119; translation mine)

Beginning anew, or gesturing toward a potential course, the line of poetry accompanies the "flexible writing" of the essay, verse giving way to a multiplicity of more unassignable forms: "it" (Moore, Stevens), "what is possible" (Stevens), "Spring and All" (Williams-author's emphasis). Refusing the finitude of conclusions and beginnings alike, poetry thus un-defines itself, not only playing with its prosaic "negative," but also reaching out to the essay's peripheral yet intermediary domain Alastair Fowler designates as "literature in potentia" (Fowler, quoted in Obaldia, 2001 5-6), ${ }^{12}$ if not to the genre where all other genres take shape as described by Reda Bensmaïa:

One can say that the essay is not a genre like any other, and perhaps not a genre at all. Nor is the essay a mixture of genres. It does not mix genres, it complicates them, the genres its (the essay's) "fallout," the historically determined actualizations of what is potentially woven into the essay. The latter appears, then, 
as the moment of writing before the genre, before genericness, or the matrix of all generic possibilities" (Bensmaïa, 1987 91-92; author's punctuation).

From the antechamber of its own prolegomena, poetry thus opens up new generative spaces, where thought may undo the contours of disciplinary and generic categories alike, only to sketch out new potential forms. If the title of this issue suggests that we all more or less possess our object, American literature, in the face of an ungraspable "philosophical," the modernist poem, against the grain, invites us, it would seem, to let this object loose, only to chase it again, to depart from poetry for a time, to better essay the lines of the poetical.

\section{BIBLIOGRAPHY}

AGAMBEN, Giorgio. The End of the Poem. 1996. Translated from the Italian by Daniel Heller-Roazen. Stanford: Stanford University Press, 1999.

AGAMBEN, Giorgio. Stanzas: Word and Phantasm in Western Culture. 1977. Translated from the Italian by Ronald L. Martinez. Minneapolis: University of Minnesota Press, 1997.

BAILLY, Jean-Christophe. L'Élargissement du poème. Paris: Christian Bourgois Editeur, 2015.

BENSMAIA, Reda. The Barthes Effect: The Essay as Reflective Text. 1986. Translated by Pat Fedkiew. Minneapolis: University of Minnesota Press, 1987.

BOURDIEU, Pierre. “L'Institutionnalisation de l'Anomie." Les Cahiers du Musée national d'art moderne, no. 19/20, “Moderne, Modernité, Modernisme," June 1987, p. 6-19.

COLLOMB, Michel. “La Tradition Moderne." Les Cahiers du Musée national d'art moderne, no. 19/20, “Moderne, Modernité, Modernisme," June 1987, p. 52-59.

CRITCHLEY, Simon. Things Merely Are: Philosophy in the Poetry of Wallace Stevens. London: Routledge, 2005.

ELIOT, T.S. The Sacred Wood: Essays on Poetry and Criticism. London: Methuen \& co., 1920.

HONIGSBLUM, Bonnie. “Marianne Moore's Revisions of 'Poetry.”' Marianne Moore: Woman and Poet. Ed. Patricia Willis. Orono, ME: National Poetry Foundation, 1990, p. 185-222.

JULLIEN, François. The Book of Beginnings. 2012. Translated from the French by Jody Gladding. New Haven: Yale University Press, 2015.

MACLEISH, Archibald. Collected Poems, 1917-1982. Boston: Houghton Mifflin Company, 1985.

MALLARMÉ, Stéphane. Divagations. Paris: Eugène Fasquelle, 1897.

MALLARMÉ, Stéphane. Un Coup de dés jamais n'abolira le hasard. Paris: Nouvelle Revue Française, 1914.

MAO, Douglas. Solid Objects: Modernism and the Test of Production. Princeton, NJ: Princeton University Press, 1998.

MICHAUD, Yves (Dir.). Les Cahiers du Musée national d'art moderne, no. 19/20, “Moderne, Modernité, Modernisme", 1987. 
MOORE, Marianne. Becoming Marianne Moore: The Early Poems, 1907-1924. Ed. Robin G. Schulze. Berkeley: University of California Press, 2002.

MOORE, Marianne. The Complete Poems of Marianne Moore. 1967. New York: Macmillan/Viking 1981. NORTH, Michael. Novelty: A History of the New. Chicago: The University of Chicago Press, 2013. OBALDIA, Claire De. The Essayistic Spirit: Literature, Modern Criticism and the Essay. Oxford: Clarendon Press, 2001.

OUDART, Clément. "Modernist Revolutions: American Poetry and the Paradigm of the New." Transatlantica [Online], 1 | 2016, Online since 18 February 2017, connection on 11 November 2020. doi.org/10.4000/transatlantica.8187

PERELMAN, Bob. “The Marginalization of Poetry.” The Marginalization of Poetry: Language Writing and Literary History. Princeton, NJ: Princeton University Press, 1996, p. 3-10.

PERLOFF, Marjorie. The Futurist Moment: Avant-Garde, Avant-Guerre, and the Language of Rupture. Chicago: University of Chicago Press, 1986.

PERLOFF, Marjorie. “Pound/Stevens: Whose Era?" New Literary History, vol. 13, no. 3, 1982, p. 485-514.

PREMINGER, Alex, T.V.F. BROGAN, et al., eds., The New Princeton Encyclopedia of Poetry and Poetics. Princeton, NJ: Princeton University Press, 1993.

POUND, Ezra. Literary Essays of Ezra Pound. New York: New Directions, 1954.

RABATÉ, Jean-Michel. "La Tradition du neuf : introduction au modernisme anglo-saxon." Les Cahiers du Musée national d'art moderne, no. 19/20, “Moderne, Modernité, Modernisme," June 1987, p. 94-109.

ROSENBERG, Harold. The Tradition of the New. Chicago: University of Chicago Press, 1982.

SCHULZE, Robin. "Textual Darwinism: Marianne Moore, the Text of Evolution, and the Evolving Text.” Text, vol. 11, 1998, p. 270-305.

STEVENS, Wallace. Collected Poetry and Prose. New York: Library of America, 1997.

UTARD, Juliette. Wallace Stevens: Une Poétique du Fini, Paris: Honoré Champion, 2018.

WHITE, Eric B. "William Carlos Williams and the Local." The Cambridge Companion to William Carlos Williams. Ed. Christopher MacGowan. New York: Cambridge University Press, 2016, p. 8-23.

WILLIAMS, William Carlos. The Autobiography of William Carlos Williams. New York: Random House, 1951.

WILLIAMS, William Carlos. I Wanted to Write a Poem: The Autobiography of the Works of a Poet. Ed. Edith Heal, Boston: Beacon Press, 1958.

WILLIAMS, William Carlos. Imaginations. Ed. Webster Schott. New York: New Directions, 1971.

WILLIAMS, William Carlos. Paterson. 1946-1958. New York: New Directions, 1995.

\section{NOTES}

1. "How to begin to find a shape-to begin to begin again" (Williams, 1995 140).

2. Bob Perelman aptly reasserts the intellectual significance of poetic margins, beyond reductive visions of verse as mere "chopped up" prose, in a generically ambivalent essay in verse entitled "The Marginalization of Poetry": 
[...] is this a line break

or am I simply chopping up

ineradicable prose? But to defend this

(poem) from its own attack, I'll

say that both the flush left

and irregular right margins constantly loom

as significant events, often interrupting what

I thought I was about to

write and making me write something

else entirely. Even though I'm going

back and rewriting, the problem still

reappears every six words. So this,

and every poem, is a marginal

work in a quite literal sense. (Perelman, 1996 4).

3. For a historical overview of poetic inspiration, from ancient invocations to the muse to the romantic belief in inner genius, see Preminger and Brogan, 609-610.

4. Editor's note: see also on this question the issue of Transatlantica entitled "Modernist Revolutions: American Poetry and the Paradigm of the New."

5. See also the "Moderne, Modernité, Modernisme" issue of Les Cahiers du Musée National d'Art Moderne (1987), and more particularly Jean-Michel Rabaté, "La Tradition du Neuf" (94-109), Michel Collomb, "La Tradition Moderne" (52-59) and Pierre Bourdieu, "L'Institutionnalisation de l'Anomie" (6-19).

6. The phrase is part of the title given to Marjorie Perloff's synchronic study The Futurist Moment: Avant-Garde, Avant-Guerre, and the Language of Rupture (1986). It applies to a variety of European experiments that include, but are not limited to, Italian Futurist practices and range from "the invention of collage" (44-79) to "the manifesto as art form" (80-115). Although it does not primarily focus on the outer limits of the poem-its beginning or its end-chapter 5, "Ezra Pound and 'The Prose Tradition in Verse"" (162-193) is of particular interest for the present reflection on the generic indecision of the modernist poem: "It is a commonplace that Pound's prosodic experiments were designed to explode traditional English metrics: 'To break the pentameter, that was the first heave.' But the breaking of the pentameter was only one step in a much more radical development of the avant guerre, namely, the breaking down of the binary opposition between verse and prose, as those two terms were understood at the turn of the century" (164-165).

7. As Michael North points out in his critique of philosophical, scientific or artistic concepts of "novelty," Ezra Pound's injunction to "Make It New!" (sic) though taken up as a convenient slogan by scholars of Modernism was actually the result of a long and complex genealogy. Not only does the original Chinese phrase suggest a different interpretation based as much on renewal as on repetition, but it was also translated and glossed so many times, from ancient Confucian sources to Pound's own writings, as to constitute "in fact a dense palimpsest of historical ideas about the new." (North, 2013 162-163) For a more general appreciation of Modernist and critical constructions of the new, see North's chapter "Making It New: Novelty and Aesthetic Modernism" (North, 2013, 141-168).

8. In his autobiography, Williams recalls the early influence of John Dewey's pragmatist philosophy, synthesized by the formula: "The local is the only universal, upon that all art builds." (Williams, 1951 391) Dewey's thought played a crucial part in the elaboration of Williams' localist poetics, against the more cosmopolitan or Europe-centered trends of avant-garde poetry. See Eric B. White, 8-23.

9. Agamben, 1997 xviii-xix. 
10. "The encounter between Sigmund Freud, Traumdeuter, and H. D., Imagiste, thus unquestionably figures one of modernism's defining passages, from an older tradition in which the object appears principally as a signifier of something else or a component of scenic plenitude to a newer order in which its value depends neither on metaphoricity nor on marginality" (Mao, 1998 xxvii).

11. For an overview of the numerous editorial changes undergone by "Poetry," see for instance Bonnie Honigsblum, 1990 185-222; and Robin Schulze, 1998 270-305.

12. "The essay, then, is not so much excluded from the realm of literature as relegated to the latter's margins. Its borderline position between the purely literary and the purely scientific or philosophical gives it a recognizable affinity to those other genres which Alastair Fowler most appropriately groups under the concept of 'literature in potentia': 'According to the central conception, 'literature' refers to a certain group of genres, whose exemplars are therefore by definition literary, at least in aspiration. These central genres comprise the poetic kinds, the dramatic, and some of the prose kinds. [...] Round this nucleus spreads a looser plasma of neighboring forms, essay, biography, dialogue, history and others. They are, so to say, literature in potentia."' (Obaldia, 2001 5-6). Interestingly here, the poetic genre is viewed as one of the more stable bearings of "literature."

\section{ABSTRACTS}

Starting from Giorgio Agamben's observation that "the end of the poem" is threatened by generic indefiniteness, this article explores what occurs when, on the other end, the text refuses to begin, postponing its own formulation in favor of a never-ending foreword. Far from enabling an absolute contact between words and things that would settle once and for all the ambiguous relationship between reality and imagination, the seemingly close unit of the poem or collection, more particularly as it was expressed by American modernism, is thus jeopardized, the text being assigned to the virtuality of a "placeless place" (Aristotle; Agamben) where poetry and philosophy may meet. Refusing its own closure, the page of the poem, through the fluctuations of its contours and the engagements it stages, joins the tentative field of the essay, thereby abolishing generic categories as much as the Platonic scission between philosophical and poetical words.

Partant du constat que livre Giorgio Agamben sur l'indéfinition générique qui menace « la fin du poème ", cet article examine ce qui se joue en parallèle lorsque le texte se refuse à tout à fait commencer, différant sa propre formulation au profit d'un avant-propos sans cesse relancé. Loin de fournir le lieu et le moment privilégiés d'un contact absolu entre les mots et les choses, qui réglerait une fois pour toutes les termes du commerce équivoque entre réalité et imagination, l'unité en apparence close du poème ou du recueil, tout particulièrement tels que les formula le modernisme américain, se trouve ainsi remise en jeu, renvoyant le texte à la virtualité d'un « lieu sans lieu » (Aristote, Agamben) où faire se rencontrer poésie et philosophie. D'espace de clôture, la page du poème, par les fluctuations de sa circonférence et les élans qui s'y opèrent, se fait terrain d'essai où s'abolissent les lignes génériques autant que la scission platonicienne entre paroles philosophique et poétique. 
INDEX

Mots-clés: poésie, essai, genre, commencements, Modernisme, William Carlos Williams, Wallace Stevens, Marianne Moore

Keywords: poetry, essay, genre, beginnings, Modernism, William Carlos Williams, Wallace Stevens, Marianne Moore

\section{AUTHOR}

AURORE CLAVIER

Université de Lille 